\title{
Corrigendum
}

Learning \& Memory 25: 620-628 (2018)

Corrigendum: Intermediate-term memory in Aplysia involves neurotrophin signaling, transcription, and DNA methylation

Qizong Yang, Igor Antonov, David Castillejos, Anagha Nagaraj, Caleb Bostwick, Andrea Kohn, Leonid L. Moroz, and Robert D. Hawkins

In the above-mentioned paper, one of the author names was presented without the middle initial. This should appear as Leonid L. Moroz. This has been corrected in the author line above and in the article online.

doi:10.1101/lm.049189.118 


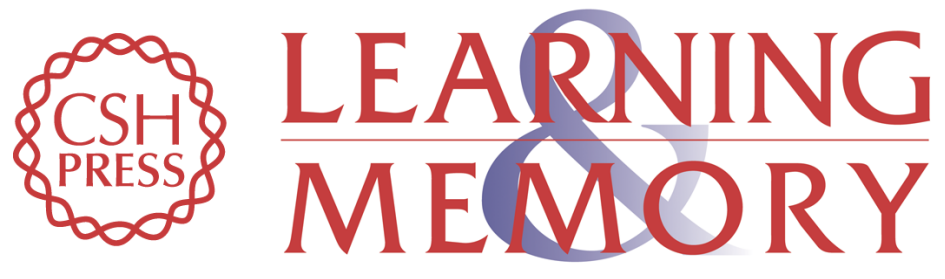

\section{Corrigendum: Intermediate-term memory in Aplysia involves neurotrophin signaling, transcription, and DNA methylation}

Qizong Yang, Igor Antonov, David Castillejos, et al.

Learn. Mem. 2019, 26:

Access the most recent version at doi:10.1101/Im.049189.118
Related Content Intermediate-term memory in Aplysia involves neurotrophin signaling, transcription, and DNA methylation
Qizong Yang, Igor Antonov, David Castillejos, et al.
Learn. Mem. December , 2018 25: 620-628

\section{License}

Email Alerting Receive free email alerts when new articles cite this article - sign up in the box at the Service top right corner of the article or click here. 